\title{
Fate of Cerium Oxide Nanoparticles in Natural Waters and Immunotoxicity in Exposed Rainbow Trout
}

\author{
Gagnon $C^{*}$, Bruneau A, Turcotte P, Pilote $M$ and Gagné $F$
}

Aquatic Contaminant Research Division, Water Science and Technology Branch, Environment and Climate Change Canada, 105 McGill Street, Montreal, Quebec, Canada

\begin{abstract}
Once released in the environment, engineered nanoparticles (NPs) can undergo important transformation resulting in changed properties under natural conditions. This study investigated the fate, the bioavailability and the immunotoxicity of cerium oxide $\left(\mathrm{CeO}_{2}\right)$ nanoparticles in fish exposed to $\mathrm{CeO}_{2}$ in representative surface waters differing in $\mathrm{pH}$, organic matter content and conductivity (green and brown waters). Following an incubation period of $\mathrm{NP} \mathrm{CeO}_{2}$ in different surface waters, particle size distribution and shape were determined by ultrafiltration and ICP-mass spectrometry, electronic microscopy and dynamic light scattering (DSL). Bioaccumulation and effect biomarkers focusing on the immune system responses (viability of immune cells and phagocytic activity) were also determined. Particle size distributions significantly changed under all types of surface waters where aggregation of NPs was commonly observed. Indeed, $>90 \%$ of $\mathrm{NPs} \mathrm{CeO}_{2}$ were found as aggregates $(>450 \mathrm{~nm}$ ) and large colloids (>100 nm). Less than $1 \%$ cerium (Ce) was found in the truly dissolved fraction $(<1 \mathrm{kDa})$ suggesting no evidence of degradation for $\mathrm{NP} \mathrm{CeO}_{2}$ in the water samples after $96 \mathrm{~h}$. The $\mathrm{NPs} \mathrm{CeO}_{2}$ were preferably accumulated in fish gills and accumulation was the highest in green waters which contained less total organic carbon (TOC), higher conductivity $(218 \mu \mathrm{S} / \mathrm{cm})$ and higher $\mathrm{pH}(7.8-8.0)$ than brown waters. The toxic properties (induced phagocytosis) of $\mathrm{NP} \mathrm{CeO}_{2}$ also differed when dispersed in brown, green and tap waters. NPs $\mathrm{CeO}_{2}$ induced fish mortality at initial concentration of $10 \mu \mathrm{g} / \mathrm{L} \mathrm{Ce}$ in both tap and green waters but not in brown waters which have different and high organic matter sources, lower $\mathrm{pH}$ and conductivity values. In conclusion, $\mathrm{NPs} \mathrm{CeO}_{2}$ tends aggregate in representative freshwater, adsorb on gills and the immunotoxic potential is reduced in the presence of high natural organic matter, mildly acidic $\mathrm{pH}$ and low conductivity as found in brown waters.
\end{abstract}

Keywords: Nanoparticle; Nanotoxicity; Bioaccumulation; Transformation

\section{Introduction}

Nanoparticles have unique commercial properties [1] and their growing use will lead to their introduction into the aquatic environment which can threaten ecosystems [2]. Cerium oxide NPs are widely used in biomedical sector as antioxidants in biological systems [3], and engineering industries, as additives in diesel fuel [4] and ceramic applications [5]. Moreover, Ce is considered the most abundant rare earth elements and intensely used by our economy. For these reasons, this metal oxide is on the list of prioritized nanomaterials by the Organization for Economic Cooperation and Development (OECD) for environmental characterization and assessment. Cerium pollution is mainly associated with landfills from leachable of solid wastes of electronic devices and sludge and wastewater discharges from industries such as ceramic plants [6]. Despite the increasing interest in the application of $\mathrm{NP} \mathrm{CeO}_{2}$ in the industry, the occurrence in the aquatic environment and potential toxicological effects to organisms still remain to be investigated as a requirement for environmental risk assessment [7]. The positive charge (Zeta potential $+30 \mathrm{mV}$ ) at the surface of $\mathrm{NP} \mathrm{CeO}_{2}$ influences their stabilization and ability of absorption to solids such as sludge. According to a survey/study in treatment plants, up to $6 \%$ of $\mathrm{CeO}_{2}$ would escape and release in the plant outflow, reaching effluents and subsequently receiving natural waters [8]. Concentrations of $\mathrm{CeO}_{2}$ in treated wastewater effluents could reach concentrations up to $1 \mu \mathrm{g} / \mathrm{L}$ [6]. Ecological assessments of NP need to address their changing physicochemical properties in environmental media. Aggregation and dissolution processes could influence exposure pathways, potential bioaccumulation in specific target tissues and therefore toxicity in aquatic organisms. However, the behaviour of $\mathrm{NP} \mathrm{CeO}_{2}$ stemming from treated municipal wastewater in the various types of surface waters is presently not well understood.

Cerium oxide nanoparticles undergo redox processes (Ce (III) and Ce (IV)) which would strongly influence their properties (e.g., catalytic ability) and behaviour of released of $\mathrm{NP} \mathrm{CeO}_{2}$ in the environment [9]. Cerium oxide NPs generally tend to quickly form large poly- dispersed aggregates. Such aggregates were characterized by Transmission Electronic Microscopy (TEM) as loose assemblage of primary particles with no clear evidence of aggregated sub-particles following degradation [10]. Compared to other more soluble metal oxide NPs, $\mathrm{NPs} \mathrm{CeO}_{2}$ were found as aggregates, but remain in NP form in pseudofeces of exposed mussels indicating high resiliency/stability of $\mathrm{NP} \mathrm{CeO}_{2}$ [11]. Natural organic matter (NOM) could interact at the surface of $\mathrm{NP} \mathrm{CeO}_{2}$ preventing their aggregation and therefore stabilizing them as monomers in suspension [12]. Several studies have investigated interactions of NOM with metal oxide NPs, mainly Ti and $\mathrm{Fe}$ [13-15]. However little is known on $\mathrm{NP} \mathrm{CeO}_{2}$ interactions with NOM, but NOM generally reduces their aggregation [12]. For example, stabilized NPs were observed by the increase in NOM from Suwannee River (USA) [16]

Compared to other metals or metal oxide NPs like NP silver and NP zinc oxide that readily dissolve in freshwater and release ionic forms upon degradation [17], $\mathrm{NPs} \mathrm{CeO}_{2}$ are much less reactive and rather remain as an insoluble form (ceramic-like aggregates) [18].

*Corresponding author: Christian Gagnon, Aquatic Contaminant Research Division, Water Science and Technology Branch, Environment and Climate Change Canada, 105 McGill Street, Montreal, Quebec, Canada, Tel: 15144967096; E-mail: christian.gagnon@canada.ca

Received: February 26, 2018; Accepted: March 05, 2018; Published: March 09 2018

Citation: Gagnon C, Bruneau A, Turcotte P, Pilote M, Gagné F (2018) Fate of Cerium Oxide Nanoparticles in Natural Waters and Immunotoxicity in Exposed Rainbow Trout. J Nanomed Nanotechnol 9: 489. doi: 10.4172/2157-7439.1000489

Copyright: ( 2018 Gagnon C, et al. This is an open-access article distributed unde the terms of the Creative Commons Attribution License, which permits unrestricted use, distribution, and reproduction in any medium, provided the original author and source are credited. 
Because of the relatively low solubility of $\mathrm{NP} \mathrm{CeO}_{2}$, this metal oxide $\mathrm{NP}$ was reported to be 10 times less accumulated in exposed marine mussels when compared to results for the more soluble $\mathrm{NP} \mathrm{ZnO}$ [11]. Cerium oxide NPs in water-exposed fish are absorbed through their gastrointestinal tract and gills [19]. However, the tendency of $\mathrm{NP} \mathrm{CeO}_{2}$ to aggregate may lead to different exposure routes which can lead to different toxicity in aquatic organisms [20]. Hence, the occurrence of $\mathrm{NP} \mathrm{CeO}_{2}$ aggregates could likely influence the immunity which is involved in the recognition and elimination of foreign particles.

In contrast to human and terrestrial toxicological investigations, $\mathrm{NP} \mathrm{CeO}$ aquatic toxicity-studies are scarce [5,21-23]. While no toxicity was observed in zebrafish embryos exposed in culture media, exposed adults in the water column led to significant bioaccumulation of $\mathrm{Ce}$ in fish liver [19,24]. Exposure of bivalves to $\mathrm{NP} \mathrm{CeO}_{2}$ at predicted concentrations $(1-100 \mu \mathrm{g} / \mathrm{L})$ resulted in significant adverse effects impacting the lysosomal system, the catalase activity and the digestive gland functions [25]. Protection against foreign materials such as xenobiotics occurs through two different components of the immune system: the first producing an immediate and nonspecific response (ie. innate immunity) and the second producing a specific response as well as an immunological memory (ie., acquired immunity). The immunological defense of most aquatic species relies mainly on the nonspecific immute response as the first line of defense and includes phagocytosis and inflammatory reactions [26]. In mussels that rely only on innate immunity, exposure to CdTe quantum dots aggregates leads to significant effects at the hemocyte viability, phagocystosis and cell lysis potential [27]. Exposure to silver NPs to fish also induced immunosuppression at the innate immunity level as well which suggests that the exposure to NPs and aggregates targets that system in aquatic organisms [28]

Several studies investigated potential impacts on fish as function of NP concentrations of unmodified (i.e., non-transformed) nanoscale metal oxides and pointed out the need to consider the exposure to transformed products as well transformation for a complete risk assessment $[12,19,29,30]$. The objectives of the study were to evaluate the transformation and behaviour of $\mathrm{NP}^{\mathrm{CeO}}$ in natural waters of different properties $(\mathrm{pH}$, conductivity and natural organic carbon) as key information for environmental impact assessment. The study reports on the bioaccumulation and immunological effects in fish exposed to primary $\mathrm{NP} \mathrm{CeO}_{2}$ and their transformation products by taking into account the fate and behavior (including aggregates and dissociated forms) of the nanoparticles in various natural aqueous matrices.

\section{Materials and Methods}

\section{Cerium oxide nanoparticle}

A stock solution of $\mathrm{NP} \mathrm{CeO}_{2}$ from Sigma-Aldrich chemical company (Ontario, Canada) was used in this study. According to the manufacturer's specifications, the $\mathrm{NP} \mathrm{CeO}_{2}$ suspension has a size $\leq 25 \mathrm{~nm}$, at a concentration of $10 \% \mathrm{wt}$ in water. For the exposure regime, rainbow trouts (Oncorhynchus mykiss) were exposed to a nominal concentration of $10 \mu \mathrm{g} / \mathrm{L}$ total $\mathrm{Ce}$ as sonicated $\mathrm{NP} \mathrm{CeO}_{2}$ in dechlorinated tap water (controls), and two types of surface waters as described below. The $\mathrm{NP} \mathrm{CeO}_{2}$ concentration was chosen according to environmental concentrations [31] and to previous standard acute tests with daphnia (Daphnia magna) and $\mathrm{NP} \mathrm{CeO}_{2}[32$.

\section{Types of water}

Three types of water, with initial contrasting water chemistry, were sampled in November 2013; green water, organic-rich brown water and UV/charcoal-treated, filtered tap water. Total organic carbon (TOC) concentrations, as well as $\mathrm{pH}$ and conductivity were measured at the beginning and at the end of the exposure (Table 1). Rainbow trouts were then exposed to $\mathrm{NP} \mathrm{CeO}_{2}$ in tap water, green and brown freshwater. Tap water consisted of dechlorinated and UV/charcoaltreated green water from the Saint-Lawrence River near the city of Montréal. Green waters were surface waters with low organic carbon content $(3.2 \mathrm{mg} / \mathrm{L})$, relatively high conductivity $(218 \mu \mathrm{S} / \mathrm{cm})$ and $\mathrm{pH}$ (7.6). Brown waters sampled in the Ottawa River were different with lower $\mathrm{pH}(6.7)$ and conductivity $(112 \mu \mathrm{s} / \mathrm{cm})$, but higher TOC $(6.4$ $\mathrm{mg} / \mathrm{L})$.

\section{Fish exposure}

Juvenile rainbow trouts (Oncorhynchus mykiss) (mean size $122.5 \pm$ $9.2 \mathrm{~mm}$; mean weight $26.3 \pm 5.5 \mathrm{~g}$ ) were provided by a local hatchery (Pisciculture des Arpents-Vert, Ste-Edwidge, Qc), maintained in 1000$\mathrm{L}$ tanks at $15^{\circ} \mathrm{C}$, fed daily with a commercial trout chow for 2 weeks and held under a natural photoperiod ( $12 \mathrm{~h}$ light: $12 \mathrm{~h}$ dark) before the initiation of exposure. The following week of water sampling, five trouts were placed in $10 \mathrm{~L}$ containers lined with polyethylene bags and exposed to $10 \mu \mathrm{g} / \mathrm{L}$ total $\mathrm{Ce}$ as $\mathrm{NP} \mathrm{CeO}_{2}$ in each type of unfiltered water for $96 \mathrm{~h}$ at $15^{\circ} \mathrm{C}$. The exposure experiment was repeated twice. The water was not renewed during the experiment. Fish were not fed and monitored daily for any signs of distress or changes in behaviour. Dissolved oxygen was maintained above $95 \%$, $\mathrm{pH}$ between 7.2-7.9, and temperature at $15^{\circ} \mathrm{C}$ during the exposure period. After the exposure period, fish were ethically euthanized with $0.1 \%$ of MS-222 (SigmaAldrich $^{\circ}, \mathrm{ON}$, Canada) using approved protocol by the Canadian Council on Animal Care Committee. The pronephros was dissected out and kept on ice for immunocompetence assessments on the same day. Liver and gills were immediately collected, weighed and stored at $-80^{\circ} \mathrm{C}$ for subsequent chemical and biochemical analyses.

\section{Characterization of $\mathrm{NP} \mathrm{CeO}_{2}$}

Transmission electron microscope (TEM) observation and electron-dispersive $\mathbf{X}$-ray analysis: A sub-sample $(50 \mathrm{~mL})$ of each type of waters was collected in duplicate after $96 \mathrm{~h}$ and kept at $4^{\circ} \mathrm{C}$ for further $\mathrm{NP} \mathrm{CeO}_{2}$ characterization. The samples as well as the stock solution were observed by TEM no longer than 3 days after the end of exposure. A drop of exposure medium was placed on a copper grid capped with a lacey carbon film for TEM analysis. Once the sample was dehydrated, it was examined by TEM (JEOL, 2100-F model) operated at $200 \mathrm{kV}$ for image capture in clear bottom. For each TEM picture, an electron-dispersive X-ray analysis (EDS) was performed for element composition of targeted particles. Maximal length (L) and width (W) were measured on the TEM pictures for the three types of water and the suspension stock in order to calculate an eccentricity ratio $(\mathrm{e}=\mathrm{L} / \mathrm{W})$ using the software ImageJ $1.51 \mathrm{~K}$ (Wayne Rasband, National Institutes of Health, USA). For the three types of water, all TEM pictures were considered in order to obtain an important event number (brown

\begin{tabular}{|c|c|c|c|c|}
\hline Exposure time & Parameters & Tap water & Green water & Brown water \\
\hline \multirow{3}{*}{$0 \mathrm{~h}$} & TOC $(\mathrm{mg} / \mathrm{L})$ & 1.9 & 3.2 & 6.4 \\
\cline { 2 - 5 } & $\mathrm{pH}$ & 7.2 & 7.6 & 6.7 \\
\cline { 2 - 5 } & Conductivity $(\mu \mathrm{S} / \mathrm{cm})$ & 284 & 218 & 112 \\
\hline \multirow{3}{*}{$96 \mathrm{~h}$} & $\mathrm{TOC}(\mathrm{mg} / \mathrm{L})$ & 11.5 & 15 & 14 \\
\cline { 2 - 5 } & $\mathrm{pH}$ & 8.0 & 7.9 & 7.5 \\
\cline { 2 - 5 } & Conductivity $(\mu \mathrm{S} / \mathrm{cm})$ & 347 & 377 & 161 \\
\hline
\end{tabular}

TOC: Total Organic Carbon.

Table 1: Characterization of waters before and after incubation. 
water $n=20$, green water $n=11$ and tap water $n=20$ ). The picture was separated in 4 equal squares and one of them was randomly chosen, all $\mathrm{NPs} \mathrm{CeO}_{2}$ were measured in this square $(\mathrm{n}=45)$.

Dynamic light scattering: Nanoparticle hydrodynamic size and Zeta potential were measured in duplicate using dynamic light scattering (DLS) (BrookHaven Instrument $\odot$, ZetaPlus/Bl-PALS) in the three types of water. Each water sample was previously filtered on a 450 $\mathrm{nm}$ membrane prior measurements to remove large aggregates. The $\mathrm{NP} \mathrm{CeO}$ stock solution was also diluted 1:10 with milli-Q water before the measurement on the DLS to improve the reading.

Size fraction distribution by filtration and ultrafiltration: Before the exposure, the $\mathrm{NP} \mathrm{CeO}_{2}$ suspensions were sonicated and characterized for their size fraction distribution (i.e., from truly dissolved to aggregate class) by a procedure previously described in Bruneau et al. [33]. Briefly, NP $\mathrm{CeO}_{2}$ solutions were fractionated by microfiltration and ultrafiltration using a parallel decreasing membrane porosity size gradient. A subsample of $250 \mathrm{~mL}$ of $\mathrm{NP} \mathrm{CeO}_{2}$ suspension in each type of water was first filtered on a membrane of $450 \mathrm{~nm}$ porosity (FHLC04700, EMD-Millipore $\odot$ ) and $40 \mathrm{~mL}$ was then sampled for total Ce determination. The $450 \mathrm{~nm}$ filtrate was passed through membranes of three different pore sizes in parallel: $100 \mathrm{~nm}$ (VCTP04700, EMD-Millipore $\odot$ ) and $50 \mathrm{~nm}$ (VMWP04700, Millipore) and $25 \mathrm{~nm}$ (VMWP04700, EMD-Millipore $\odot)$.

An ultrafiltration cell with constant agitation was used (Amicon ${ }^{\circ}$ 400 system, EMD-Millipore $\odot$ ) for the ultrafiltration with $1 \mathrm{kDa}$ cutoff (about $1.5 \mathrm{~nm}$ ) (YM1 $76 \mathrm{~mm}$ diameter, EMD-Millipore $\odot$ ) to determine the potential release of low molecular weight of Ce ion and its complexes. The pressure in the system was maintained constant at $60 \mathrm{psi}$ and the sample at room temperature. The flow rate was near to 1 $\mathrm{mL} / \mathrm{min}$. This ultrafiltration step was considered to provide the "truly" dissolved ion Ce fraction. Total Ce concentrations were evaluated with an inducted-coupled plasma mass spectrometry (XSERIES 2 ICP-MS, Thermo Fisher Scientific, USA). Calibration of procedures and accuracy of the measurement were assessed with five replicates of SLRS-5 reference material (River water reference material for trace metals, National Research Council, Canada). Lanthanide element analyses in SLRS-5 were comparable to those reported in the study of Rousseau et al. [34]. In our study, the calculated limit of detection (LOD) was $0.3 \mathrm{ng} / \mathrm{L}$ and the limit of quantification (LOQ) was $0.9 \mathrm{ng} / \mathrm{L}$. Concentrations in exposure media were expressed as total Ce in $\mu \mathrm{g} / \mathrm{L}$.

\section{Cerium bioaccumulation in fish tissues}

To determine Ce loading in fish tissues, livers and gills were individually sampled, weighed and frozen at $-80^{\circ} \mathrm{C}$ until analysis. Tissues were digested with high purity $8 \mathrm{~mL}$ of concentrated $\mathrm{HNO}_{3}$ (Seastar ${ }^{\mathrm{rut}}$ Chemical, BC, Canada), $1 \mathrm{~mL}$ of concentrated $\mathrm{HCl}$ (Seastar ${ }^{\mathrm{rat}}$ Chemical, BC, Canada), and $2 \mathrm{~mL}$ of concentrated $\mathrm{H}_{2} \mathrm{O}_{2}$ (Seastar ${ }^{\mathrm{mm}}$ Chemical, BC, Canada) added in that order. The tissues were then digested during $2 \mathrm{~h}$ with increasing temperature gradient (maximum $180^{\circ} \mathrm{C}$ ) using a microwave digestion system (Ethos EZ, Milestone Scientific ${ }^{\text {Inc }}$, ON, Canada). Each digested tissue sample was then placed in a $15 \mathrm{~mL}$-polyethylene tube and the final volume was adjusted to 12 $\mathrm{mL}$ with deionized water. Total Ce concentration was determined by ICP-MS (XSERIES 2 ICP-MS, Thermo Fisher Scientific, USA). For each digestion series, triplicates of dogfish liver certified reference material for trace metals (DOLT-5, National Research Council, Canada) were used to insure the reproducibility of the extraction method. The calculated LOD is $0.012 \mu \mathrm{g} / \mathrm{g}$ and the LOQ is $0.03 \mu \mathrm{g} / \mathrm{g}$. Concentrations in tissues were expressed as total Ce in $\mu \mathrm{g} / \mathrm{mg}$ wet tissues.

\section{Immune parameters}

The effects of $\mathrm{Np} \mathrm{CeO}_{2}$ were determined at the innate immunity level in exposed fish $[28,35,36]$. Immunocompetence was determined in duplicate in freshly prepared leucocytes using flow cytometry $[26,37]$. Briefly, leucocytes were extracted from the pronephros and isolated by centrifugation on a $51 \%$ Percoll $^{\circ}$ gradient at $400 \mathrm{~g}, 30$ min and $20^{\circ} \mathrm{C}$ (Sigma-Aldrich ${ }^{\circ}$, ON, Canada). The leucocyte fraction, which partitioned at the Percoll-media interface, was collected and resuspended in phosphate buffered saline (PBS: $140 \mathrm{mM} \mathrm{NaCl}, 1 \mathrm{mM}$ $\mathrm{KH}_{2} \mathrm{PO}_{4}$ and $1 \mathrm{mM} \mathrm{NaHCO}, \mathrm{pH}$ 7.4) and centrifuged at $400 \mathrm{~g}$ for 10 min at $20^{\circ} \mathrm{C}$. The cells were then resuspended in $1 \mathrm{~mL}$ of RPMI cell culure media for cell counting and viability determination using trypan blue (dead cells remain blue). Observations and cell counting were done on a hemocytometer at 200x enlargement.

Viability of immune cells was performed according to an adapted method from Brousseau et al. [26,37]. The leucocyte cell fraction was diluted at a concentration of 2 million viable cells $/ \mathrm{ml}$ in RPMI (Roswell Park Memorial Institute) media containing 10\% fetal bovine serum (FBS), and $100 \mathrm{U} / \mathrm{mL}$ penicillin, $100 \mu \mathrm{g} / \mathrm{mL}$ streptomycin and 10 mM HEPES (4-(2-Hydroxyethyl) piperazine-1-ethanesulfonic acid)), $\mathrm{pH} 7.4$, and incubated in the dark for an additional $18 \mathrm{~h}$ at $15^{\circ} \mathrm{C}$ in duplicate. After this incubation, cells were washed and resuspended in RPMI as described above. Viability was observed by flow cytometry using propidium iodide (PI) (Sigma-Aldrich ${ }^{\circ}, \mathrm{ON}$, Canada). A $4 \mu \mathrm{L}$ aliquot of PI $(100 \mu \mathrm{g} / \mathrm{mL})$ was added to $200 \mu \mathrm{L}$ of each cell suspension for $5 \mathrm{~min}$ on ice before measurement. Propidium iodide fluorescence was analyzed with a flow cytometer equipped with an argon laser excitation $\left(\lambda=488 \mathrm{~nm} \pm 10 \mathrm{~nm}\right.$ ) (Guava ${ }^{\circledR}$ Easycyte, EMD-Millipore $\odot$, USA). Fluorescence for each sample was measured in duplicate at $625 \mathrm{~nm}$ with $42 \mathrm{~nm}$ bandwidth, and 5000 events were registered. The proportion of lymphocytes and monocytes, which are the main subpopulations of leucocytes with granulocytes, were determined on the basis on the forward (cell volume) and side (cell internal complexity) scatter dot plots using the software instrument. Lymphocytes are generally smaller cells and have a more homogeneous cytoplasm than monocytes.

Phagocytosis activity was measured following the protocol of Brousseau et al. [26,37]. Briefly, $1 \mathrm{ml}$ of adjusted cell concentration ( 2 million $/ \mathrm{ml}$ ) was added to 24 cell culture-coated well plates in duplicate. Cells were incubated with a ratio 100:1 of fluorescent latex beads (Polysciences $\odot$, PA, USA) in order to observe the phagocytosis capacity of the cells. After an incubation period of $18 \mathrm{~h}$ at $15^{\circ} \mathrm{C}$, the cell suspensions were overlaid on 3\% serum bovine albumin in PBS and centrifuged at $400 \mathrm{~g}$ for $5 \mathrm{~min}$ to remove loosely adhered beads on the cell surface. Cell pellets were then resuspended and fixed in $0.5 \%$ formaldehyde and $0.2 \%$ sodium azide in PBS. Cells containing Latex bead-fluorescence were measured using an argon laser flow cytometer at $530 \mathrm{~nm}$ emission as described above, and at least 10000 events were registered. The immunoactivity was defined as the number of cells containing at least one bead and the immunoefficiency as the number of cells containing three beads or more.

\section{Data analysis}

Differences between the biomarkers were examined using a one way ANOVA when data normality was confirmed using Kruskal Wallis normality test. There were 6 treatments in the present study design: 1-3) fish exposed to control water (3 types) only; 4) fish exposed to tap water and $10 \mu \mathrm{g} / \mathrm{L} \mathrm{Ce}$ as $\left.\mathrm{CeO}_{2} \mathrm{NP}, 5\right)$ fish exposed to green water and $10 \mu \mathrm{g} / \mathrm{L} \mathrm{Ce}$ as $\mathrm{CeO}_{2} \mathrm{NP}$ and 6) fish exposed to brown water and 
Citation: Gagnon C, Bruneau A, Turcotte P, Pilote M, Gagné F (2018) Fate of Cerium Oxide Nanoparticles in Natural Waters and Immunotoxicity in Exposed Rainbow Trout. J Nanomed Nanotechnol 9: 489. doi: 10.4172/2157-7439.1000489

Page 4 of 8

$10 \mu \mathrm{g} / \mathrm{L} \mathrm{Ce}$ as $\mathrm{CeO}_{2}$ NP. A post-hoc Tukey test was used to determine the differences between the groups. When the data were not normal, a Kruskal Wallis non-parametric ANOVA was used and critical difference between treatments were appraised using the MannWhitney rank test. Significance was set at $\mathrm{p}<0.05$.

\section{Results and Discussion}

\section{Characterization of $\mathrm{NP} \mathrm{CeO}_{2}$}

In stock suspension, $\mathrm{NPs}_{\mathrm{CeO}}$ were retrieved in small aggregate forms (Figure 1). Dynamic light scattering (DLS) analyses revealed that $\mathrm{NPs} \mathrm{CeO}_{2}$ left after filtration were smaller (mean $16.9 \mathrm{~nm}$ ) in tap water, than $\mathrm{NP} \mathrm{CeO}_{2}$ in brown $(32.0 \mathrm{~nm})$ and in green water $(26.1 \mathrm{~nm})($ Table 2). The eccentricity ratios were $1.50( \pm 0.35), 1.50( \pm 0.50), 1.78( \pm 0.85)$, for brown, green and tap water respectively, revealing no significant difference in shape among the three types of matrice and confirming the stability of $\mathrm{NP} \mathrm{CeO}_{2}$ in natural waters after short-term exposure. In the stock suspension the measured eccentricity ratio was $1.53( \pm 0.44)$ and was close to the eccentricity ratios measured in brown and green waters. As observed on TEM images, $\mathrm{NPs} \mathrm{CeO}_{2}$ were retrieved as small aggregates and maintained their geometric form (Figure 2). No significant modification of the NP shape was observed with each water types. This is in contrast with other reported observations with NP

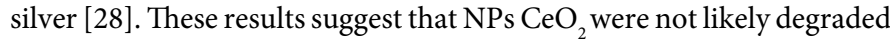
during the exposure period and were bioavailable as NP forms.

\section{Size distribution of $\mathrm{NP} \mathrm{CeO}_{2}$}

At the beginning of the exposure, the nominal Ce concentrations
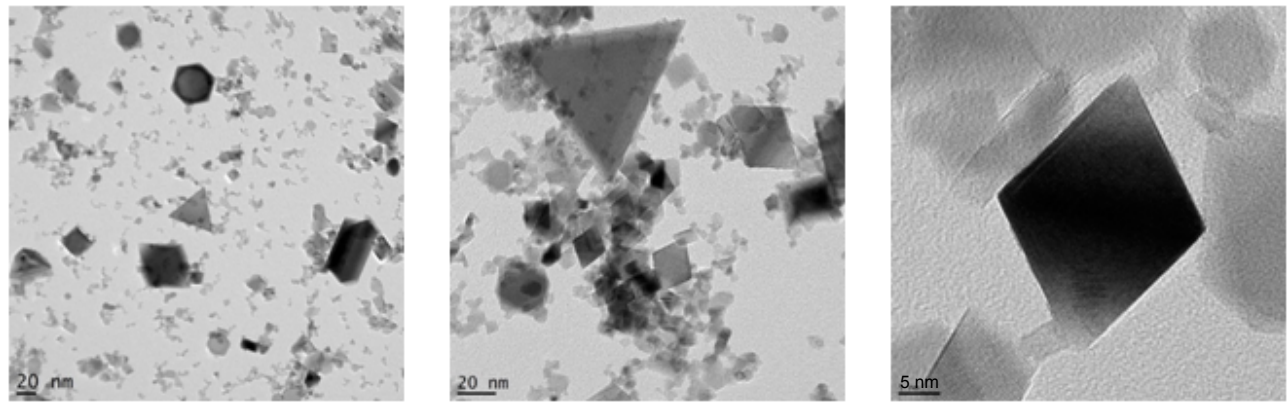

Figure 1: Transmission Electron Microscope (TEM) of $\mathrm{NP} \mathrm{CeO}_{2}$ in Sigma ${ }^{\circledR}$ stock solution. Nanoparticle suspension was heterogeneous. Different shapes were observed in the three pictures (cube, hexagon, diamond, and triangle). The scale bars indicate $20 \mathrm{~nm}$ and $5 \mathrm{~nm}$.

\begin{tabular}{|c|c|c|c|}
\hline Parameter & Tap water & Green water & Brown water \\
\hline Mean diameter size $(\mathrm{nm})$ & $16.9 \pm 3.9$ & $32.0 \pm 2.9$ & $26.1 \pm 3.2$ \\
\hline Zeta potential $(\mathrm{mv})$ & $-0.18 \pm 0.10$ & $-0.00 \pm 0.01$ & $-0.03 \pm 0.03$ \\
\hline
\end{tabular}

Table 2: Mean diameter size and Zeta potential of $\mathrm{NP} \mathrm{CeO}_{2}$ in water after exposure. These results were observed with a DLS after filtration through a membrane of 0.45 $\mu \mathrm{m}$ in order to remove large aggregates and measure the mean diameter size of the remaining particles.
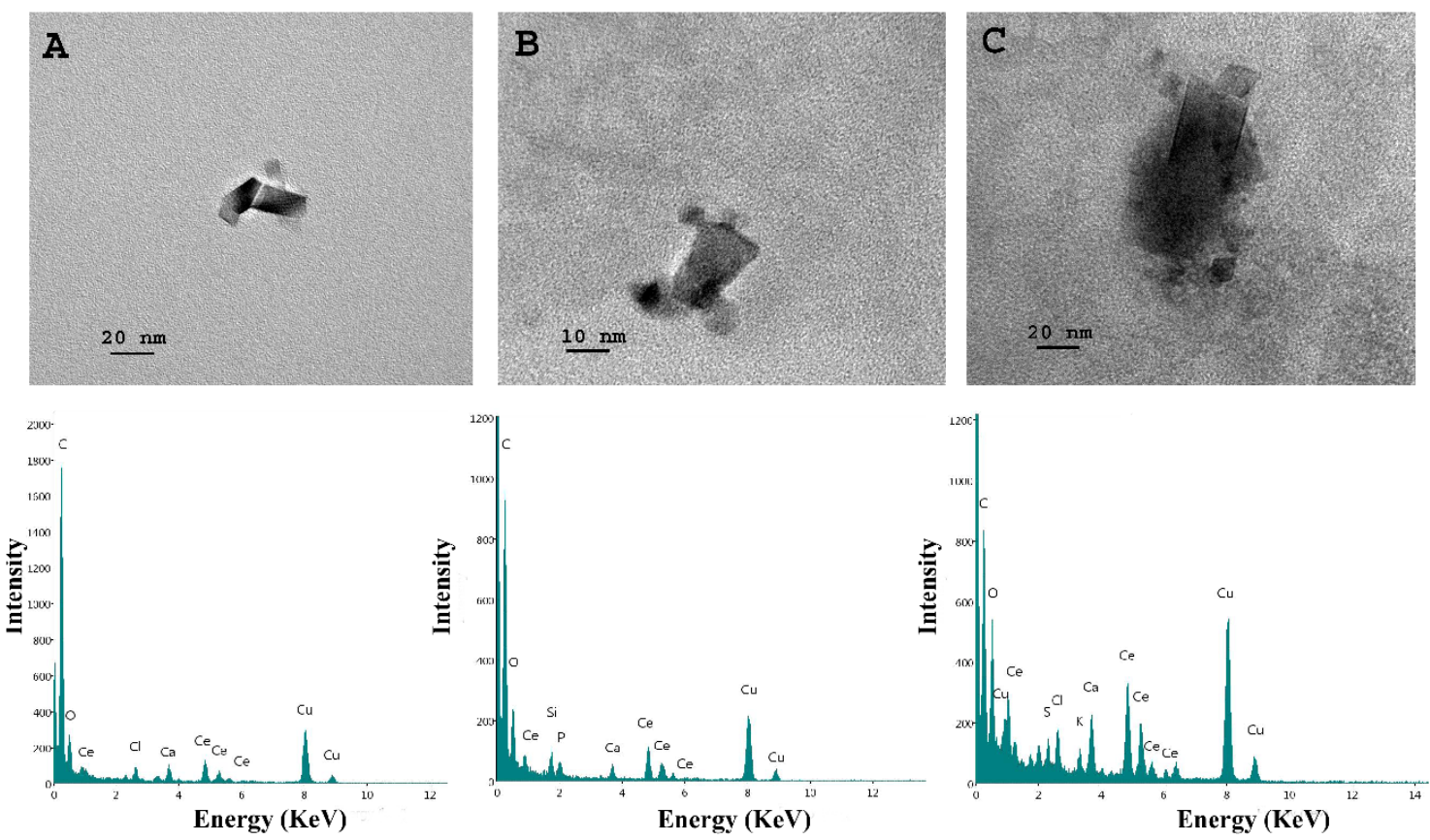

Figure 2: Cerium oxide NP morphology in A) tap water, B) green water and C) brown water after $96 \mathrm{~h}$ exposure. $\mathrm{NPs}_{\mathrm{CeO}}$ were retrieved in small aggregates. The energy dispersive spectra (EDS) elemental analysis data are presented below and confirm that $\mathrm{A}, \mathrm{B}$ and $\mathrm{C}$ show Ce-based particles. 
were relatively constant at 7.5, 11 and $8 \mu \mathrm{g} / \mathrm{L}$ for tap, green and brown waters respectively. After $96 \mathrm{~h}$, Ce concentrations in water were 3.4, 2.9 and $3.6 \mu \mathrm{g} / \mathrm{L}$ in tap, green and brown waters respectively, confirming the equilibrium of the exposure concentrations and observed settlement. After the exposure period, TOC concentrations were increased for each type of water indicating a release of carbon from the fish during the exposure. During the exposure, $\mathrm{pH}$ increased in tap and green waters and decreased in brown water (Table 1). Initial $\mathrm{NP} \mathrm{CeO}_{2}$ suspension became homogenous during the exposure as small NPs still available in the water column and aggregates settled to the bottom of the tank. This hypothesize was in agreement with the TEM picture and the DLS sizes (Figure 2).

After a first filtration step on $450 \mathrm{~nm}$, only $10 \%, 3 \%$ and $7 \%$ of $\mathrm{Ce}$ from $\mathrm{NP} \mathrm{CeO}_{2}$ were measured in tap, green and brown water respectively; indicating that more than $90 \%$ of Ce was preferentially linked to large particles $\geq 450 \mathrm{~nm}$ (Figure 3). After a filtration step on $50 \mathrm{~nm}$, less than $1 \%$ of the Ce was measured in waters, confirming that $\mathrm{NPs} \mathrm{CeO}_{2}$ were preferentially retrieved in aggregates. Large aggregates were observed for natural waters compared to the reference tap water.

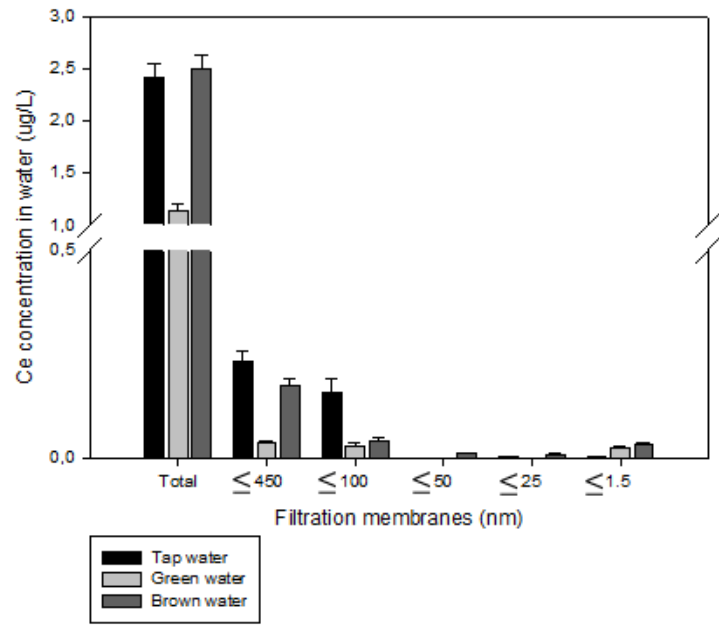

Figure 3: Concentration of $\mathrm{Ce}$ in each type of water after $96 \mathrm{~h}$ exposure. Total corresponds to the non-filtered fraction, $450 \mathrm{~nm}, 100 \mathrm{~nm}, 50 \mathrm{~nm}$, and $25 \mathrm{~nm}$ stands for the filtered fractions; $1 \mathrm{kDa}(1.5 \mathrm{~nm})$ corresponds to the ultra-filtered fraction, the so-called truly dissolved fraction $\left(\mathrm{Ce}^{2+}\right)$.
Smaller aggregates $(<100 \mathrm{~nm})$ were found in the reference tap water. The aggregation of $\mathrm{NP} \mathrm{CeO}_{2}$ in natural green and brown waters was observed, but to a lesser extent for the latter (Figures 2 and 3). Brown waters from the Ottawa River reduced aggregation, where more Ce was found in the filterable $(<450 \mathrm{~nm})$ fraction compared to the green water. No dissolved Ce, however, was detected in the $1 \mathrm{kDa}(\approx 1.5 \mathrm{~nm})$ fraction suggesting low degradation of the $\mathrm{NP} \mathrm{CeO}_{2}$ during the exposure with the three types of water.

\section{Bioaccumulation of $\mathrm{NP} \mathrm{CeO}_{2}$ in fish tissues}

Significant increases in Ce concentrations compared to the control were observed in trout gills exposed to each type of water (Figure 4A). This result could indicate that $\mathrm{NP} \mathrm{CeO}_{2}$ has a direct interaction with fish gills and was adsorbed via water contact through gills. Most $\mathrm{Ce}$ was accumulated or adsorbed in gills (one order of magnitude higher) compared to the liver. Cerium adsorption in gills was more important in green water but not significantly different (Kruskal-Wallis test) from tap and brown waters. In addition, some trout mortality (unpublished data) was observed in green water suggesting that the green water would promote adsorption of $\mathrm{NP} \mathrm{CeO}_{2}$ and induce harmful effect on fish compared to the two other types of water. A significant bioaccumulation of Ce was only observed in the trout liver exposed to $\mathrm{NPs}_{\mathrm{CeO}}$ in brown water compared with fish exposed to NPs in other waters, but at one order of magnitude less than the levels found in gills (Figure 4B). Uptake of $\mathrm{NP} \mathrm{CeO}_{2}$ was also observed in the liver of zebrafish via the water column [19]. Our findings confirm that NP $\mathrm{CeO}_{2}$ were bioavailable to fish external tissues (gills) as well with low distribution in internal organs such as the liver. For such nano-sized material and larger particles, the gastrointestinal tract was suggested as the main uptake pathway for fish [38]. It would have been of interest to analyze $\mathrm{Ce}$ in the fish gut to confirm whether fish ingested $\mathrm{Ce}$ aggregates. In mussels exposed to $\mathrm{Ce}$ and $\mathrm{Zn}$ oxide nanoparticles, substantial amounts of these elements in the pseudofeces were detected [11]. Mussels exposed to $10 \mathrm{mg} / \mathrm{L} \mathrm{Ce}$ or $\mathrm{Zn}$ oxide nanoparticles rejected $21 \mathrm{mg} / \mathrm{g}$ and $63 \mathrm{mg} / \mathrm{g}$ of $\mathrm{Ce}$ and $\mathrm{Zn}$ in the pseudofeces while they were accumulated in tissues at 62 and $880 \mu \mathrm{g} / \mathrm{g}$ on a dry weight basis suggesting that $\mathrm{Ce}$ was bioavailable to mussels albeit one order of magnitude less than $\mathrm{Zn}$.

\section{Biomarkers}

Viability: Significant decreases in both lymphocyte and monocyte viability were observed between control and $\mathrm{NP} \mathrm{CeO}_{2}$ treatments for

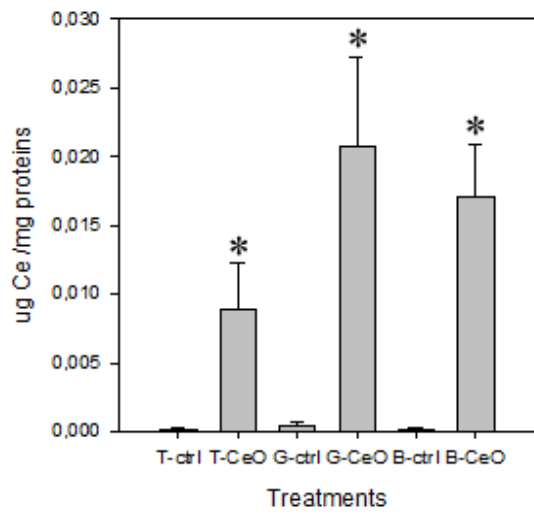

A

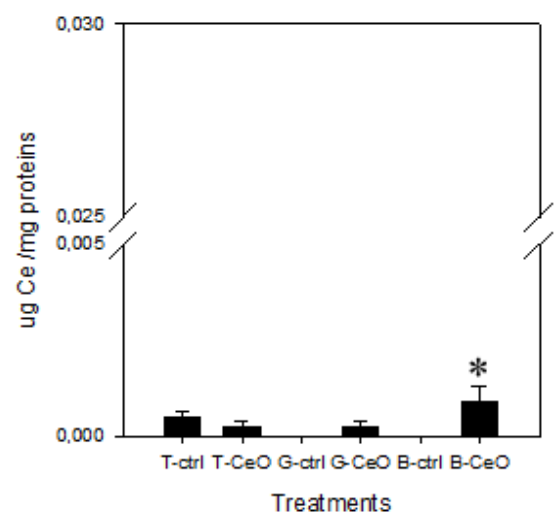

B

Figure 4: Cerium concentrations ( $\mu \mathrm{g} / \mathrm{mg}$ wet tissues) in A) gills and $\mathrm{B}$ ) liver of rainbow trout exposed and non-exposed to $\mathrm{NP}_{\mathrm{CeO}}$. Error bars correspond to standard error ( ${ }^{*}$ means $\left.p<0.05\right)$. Ctrl: Control; T: Tap water; G: Green water; B: Brown water. 

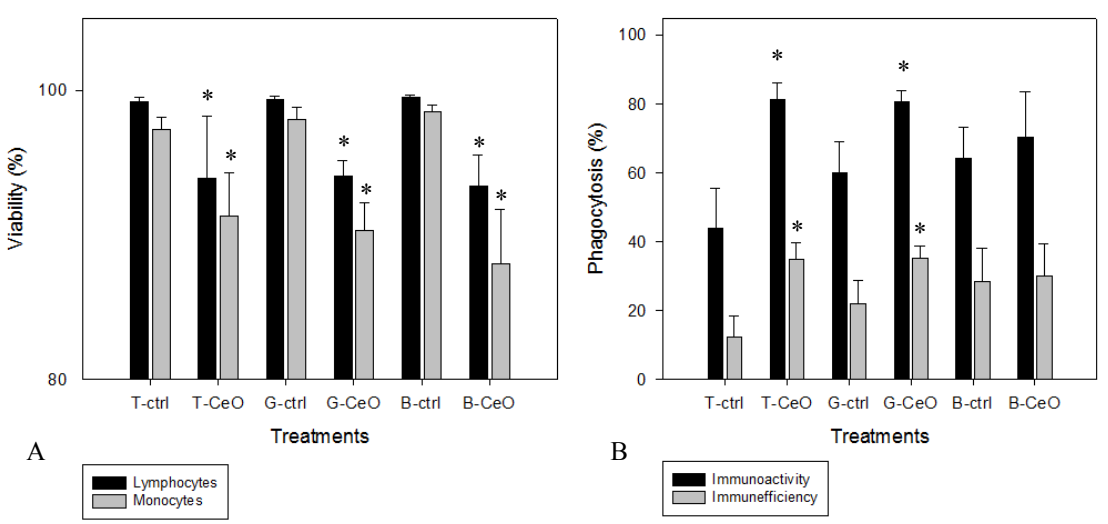

Figure 5: The A) viability and B) phagocytosis (immunoactivity and immunoefficiency) of leucocytes for rainbow trout exposed and non-exposed to NP CeO ${ }_{2}$. Error bars correspond to standard deviation ( ${ }^{*}$ means $p<0.01 . n=5$ fish/treatment). Ctrl: Control; T: Tap water; G: green water; B: brown water.

the three types of water, indicating a cytotoxic effect of NP during short exposure (Figure 5A). This suggests that the main driver of cytotoxicity was $\mathrm{NP} \mathrm{CeO}_{2}$ concentration and not the surface water types. To best of our knowledge, this is the first study on the immunotoxicity of NP $\mathrm{CeO}_{2}$ on fish leukocyte populations. Cerium oxide NPs were found to induce apoptosis and autophagy in human peripheral blood monocytes [39]. This response was induced at high concentrations $(1-10 \mathrm{mg} / \mathrm{L} ; 40$ h) due to aggregation by the high salt contents in the culture medium. In another study with human hepatoma cells, decreased viability was produced at $20 \mu \mathrm{g} / \mathrm{L} \mathrm{NP} \mathrm{CeO}{ }_{2}(20 \mathrm{~nm}$ diameter) after $70 \mathrm{~h}$ incubation time [22]. A different exposure to large bulk of $\mathrm{CeO}_{2}$ particles $(5 \mu \mathrm{m})$ was equally toxic to these cells suggesting that the primary interaction of $\mathrm{NP} \mathrm{CeO}_{2}$ is similar to large particles and surface interactions at the outer cytoplasmic membrane are at play.

Phagocytosis: Significant stimulations were observed between control and exposed treatments for tap and green waters. However, non-significant immunoactivity and immunoefficiency (as per definition in the methods section) was observed with $\mathrm{NP}^{\mathrm{CeO}}$ in brown water (Figure 5B). Similarly, ecotoxicological studies using different biomarkers classified $\mathrm{NP} \mathrm{CeO}_{2}$ in natural waters as pollutants with low in vivo toxicity $[2,23,38]$. Data on the immunotoxicity in fish of $\mathrm{CeO}_{2}$ as powder or nanoparticles are rather scarce. The exposure concentration used in the present study $(10 \mu \mathrm{g} / \mathrm{L})$ was kept at reported levels of Ce in wastewater and more than one order of magnitude below the estimated probable no-effect concentration of $\mathrm{NP} \mathrm{CeO}_{2}$ between 3-5000 mg/L depending on the species [40]. Algae were the most sensitive species towards $\mathrm{NP} \mathrm{CeO}_{2}$ compared to daphnia (Daphnia magna), beaver-tail fairy shrimp (Thamnocephalus playtures) and zebra fish (Danio rerio) embryos. According to the study of van Hoecke [40], the acute toxicity of $\mathrm{NP} \mathrm{CeO}_{2}$ would be reached at concentration $>5000 \mathrm{mg} / \mathrm{L}$ in aquatic ecosystems but mechanisms such as altered embryos hatching could be observed following $72 \mathrm{~h}$ exposure to $200 \mathrm{mg} / \mathrm{L}$ of $\mathrm{NP} \mathrm{CeO}_{2}$ of $20 \mathrm{~nm}$ and chronic toxicity for green algae at lower concentrations (2.6-5.4 $\mathrm{mg} / \mathrm{L}$ ).

In another study, $\mathrm{NPs} \mathrm{CeO}_{2}$ were not considered toxic compared with bulk $\mathrm{CeO}$ powder at $0-10 \mathrm{mg} / \mathrm{L}$ concentration range for daphnia (Daphnia magna) and 0.01-0.1 mg/L for common carp (Cyprius carpio) [38]. Nevertheless, in the present study exposure to $\mathrm{NP} \mathrm{CeO}_{2}$ at $10 \mu \mathrm{g} / \mathrm{L}$ decreased cell viability in lymphocytes and monocytes and increased phagocytosis in macrophages for tap and green waters for the latter. The innate immune system involves the recognition of foreign particles (such as NP and their aggregates) and ingestion by macrophages through the process of phagocytosis [4]. Ingested NPs would be then degraded in phagolysosomes with the production of reactive oxygen species (ROS), and hydrolytic enzymes [17]. Since phagocytosis involves the generation of ROS, the presence of $\mathrm{NP} \mathrm{CeO}_{2}$ aggregates could stimulate the phenomenon at first by scavenging radicals during the oxidative burst. Moreover, this metal oxide NP was reported as an active redox catalyst with potential for oxidative stress $[41,42]$. Several studies have shown that exposure to $\mathrm{NP}^{\mathrm{CeO}}$ can result in oxidative stress, inflammation and DNA damage to organisms $[18,20]$. During the phagocytosis, the degradation of NPs and release of elements from which the NPs are derived occur and could lead to cytotoxicity. In marine mussels, hemocytes exposed in vitro to NP $\mathrm{CeO}_{2}$ decreased viability and phagocytosis were observed in hemocytes but at concentrations $(7 \mathrm{mg} / \mathrm{L})$ much higher than in the present study [43]. The oxidative effect of $\mathrm{NP} \mathrm{CeO}_{2}$ would be coupled to the reduction of $\mathrm{Ce}(\mathrm{IV})$ to $\mathrm{Ce}(\mathrm{III})$ at high $\mathrm{NP}$ concentrations in the $\mathrm{mg} / \mathrm{L}$ range $[20,24,44]$. In $\mathrm{NP} \mathrm{CeO}_{2}$, Ce atoms could have valence states $\mathrm{Ce}$ (III/IV) allowing the storage and the release of oxygen by the nanoparticle [45]. Various studies demonstrated that the redox state plays a large role in determining the characteristics and behaviour of $\mathrm{NP} \mathrm{CeO}_{2}[9,40,46,47]$. In agreement with this statement, we hypothesized that the source of the organic matter could play a role in the behaviour of $\mathrm{NP} \mathrm{CeO}_{2}$ in natural media affecting the defense mechanism of the aquatic organisms such as phagocytosis and the level of the ROS (reactive oxygen species) and inducing negative impacts on aquatic biota health. Further experiments are required to consolidate this statement.

\section{Conclusion}

This study raises new concerns about $\mathrm{NP} \mathrm{CeO}_{2}$ fate and toxicity to aquatic organisms. According to our observations, the commercial NP suspension was mostly found as NP aggregates in natural waters. We found that $90 \%$ of $\mathrm{NP} \mathrm{CeO}_{2}$ occurred as aggregates $(>450 \mathrm{~nm})$ regardless of the three types of water (tap, green, and brown). Cerium oxide NPs were preferentially adsorbed or bioaccumulated in gills when fish were exposed to NPs in natural waters. After $96 \mathrm{~h}$, the only significant increase in Ce concentration in liver was observed in trouts exposed to NP in brown water. Cerium oxide NP induced phagocytosis in fish maintained in tap and green waters. More investigation is required on the fate of $\mathrm{NPs}^{\mathrm{CeO}}$ of different sizes in natural media with variable properties (eg., organic matter concentrations and quality) and their subsequent effects to aquatic organisms.

\section{Acknowledgments}

We thank Jean-Philippe Masse from the $\mathrm{CM}^{2}$ (Centre de Caractérisation 
Citation: Gagnon C, Bruneau A, Turcotte P, Pilote M, Gagné F (2018) Fate of Cerium Oxide Nanoparticles in Natural Waters and Immunotoxicity in Exposed Rainbow Trout. J Nanomed Nanotechnol 9: 489. doi: 10.4172/2157-7439.1000489

Microscopique des Matériaux École Polytechnique de Montréal, Montréal, Canada) for supplying the TEM images. We also thank Gwenaël Chamoulaud from NanoQam (Université du Québec à Montréal, Montréal, Canada) for the DLS analyses. This work was supported by the Environment Canada's Chemicals Management Plan.

\section{Declaration of Interest Statement}

All authors report no conflict of interest.

\section{References}

1. Dawson T (2008) Nanomaterials for textile processing and photonic applications. Color Technol 124: 194-199.

2. Brunner TJ, Wick P, Manser P, Spohn P, Grass RN, et al. (2006) In Vitro cytotoxicity of oxide nanoparticles: Comparison to asbestos, silica and the effects of particle solubility. Environ Sci Technol 40: 4374-4381.

3. Charbgoo F, Bin Ahmad M, Darroudi M (2017) Cerium oxide nanoparticles: green synthesis and biological applications. Int J Nanomedicine 12: 1401-1413.

4. Park EJ, Bae E, Yi J, Kim Y, Choi K, et al. (2010) Repeated-dose toxicity and inflammatory responses in mice by oral administration of silver nanoparticles. Environ Toxicol Pharmacol 30: 162-168.

5. Eom HJ, Choi J (2009) Oxidative stress of CeO2 nanoparticles via p38-Nrf-2 signaling pathway in human bronchial epithelial cell, Beas-2B. Toxicol Lett 187 77-83.

6. Keller AA, Lazareva A (2014) Predicted releases of engineered nanomaterials: From global to regional to local. Environ. Sci Technol Lett 1: 65-70.

7. Dahle JT, Arai Y (2015) Environmental geochemical of Cerium: Application and toxicology of cerium oxide nanoparticles. Int J Environ Res Public Health 12: 1253-1278.

8. Limbach LK, Bereiter R, Mueller E, Krebs R, Gaelli R, et al. (2008) Removal of oxide nanoparticles in a model wastewater treatment plant: Influence of agglomeration and surfactants on clearing efficiency. Environ Sci Technol 42: 5828-5833.

9. Dahle JT, Livi K, Arai $\mathrm{Y}$ (2015) Effects of $\mathrm{pH}$ and phosphate on $\mathrm{CeO} 2$ nanoparticle dissolution. Chemosphere 119: 1365-1371.

10. Rouquerol J, Avnir D, Fairbridge CW, Everett DH, Haynes JH, et al. (1994) Recommendations for the characterization of porous solids. Pure Appl Chem 66: $1739-1758$

11. Montes MO, Hanna SK, Lenihan HS, Keller AA (2012) Uptake, accumulation, and biotransformation of metal oxide nanoparticles by a marine suspensionfeeder. J Hazard Materials 225-226: 139-145.

12. Keller AA, Wang H, Zhou D, Lenthan HS, Cherr G, et al. (2010) Stability and aggregation of metal oxide nanoparticles in natural aqueous matrices. Envrion Sci Technol 44: 1962-1967.

13. Domingos RF, Tufenski N, Wilkinson KJ (2009) Aggregation of titanium dioxide nanoparticles: role of a fulvic acid. Environ Sci Technol 43: 1282-1286.

14. French RA, Jacodson AR, Kim B, Isley SL, Penn RL, et al. (2009) Influence of ionic strength, $\mathrm{pH}$ and cation valence on aggregation kinetics of titanium dioxide nanoparticles. Environ Sci Technol 43: 1354-1359.

15. Lopez-Serrano A, Sanz-Landaluze J, Muñoz-Olivas R, Cámara C (2015) Bioconcentration of ionic titanium and titanium dioxide nanoparticles in an aquatic vertebrate model: zebrafish eleutheroembryos. Nanotoxicology 9: 835842

16. Quik JTK, Lynch L, Hoecke KV, Miermans CJH, Schamphelaere KAC, et al (2010) Effects of natural organic matter on cerium dioxide nanoparticles settling in model fresh water. Chemosphere 81: 711-715.

17. Loza K, Diendorf J, Sengstock C, Ruiz-Gonzalez L, Gonzalez-Calbet JM, et al (2014) The dissolution and biological effects of silver nanoparticles in biological media. J Mater Chem B 2: 1634-1643.

18. Xia T, Kovochich M, Liong M, Madler L, Gilbert B, et al. (2008) Comparison of the mechanism of toxicity of zinc oxide and cerium oxide nanoparticles based on dissolution and oxidative stress properties. ACS Nano 2122-2134.

19. Johnston BD, Scown TM, Moger J, Cumberland SA, Baalousha M, et al. (2010) Bioavailability of nanoscale metal oxides $\mathrm{TiO}_{2}, \mathrm{CeO}_{2}$, and $\mathrm{ZnO}$ to fish. Environ Sci Technol 44: 1144-1151.
20. Rogers R, Rice KM, MAnne NDPK, Shokunfar T, He K, et al. (2015) Cerium oxide nanoparticle aggregates affect stress response and function in Caenorhabditis elegans. SAGE Open Medecine.

21. Bour A, Mouchet F, Cadarsi S, Silvestre J, Chauvet E, et al. (2016) Impacts of $\mathrm{CeO} 2$ nanoparticles on the functions of freshwater ecosystems: a microcosm study. Environ Sci Nano 3: 830-838

22. Rosenkranz $P$, Fernández-Cruz ML, Conde E, Ramírez-Fernández MB, Flores JC, et al. (2012) Effects of cerium oxide nanoparticles to fish and mammalian cell lines: An assessment of cytotoxicity and methodology. Toxicol in Vitro 26 : 888-896.

23. Rodea-Palomares I, Boltes K, Fernadez-Pinas F, Leganes F, Garcia-Calvo $\mathrm{E}$, et al. (2011) Physicochemical characterization and ecotoxicological assessment of $\mathrm{CeO} 2$ nanoparticles using two aquatic microorganisms. Toxicol Sci 119: 135-145.

24. Van Hoecke K, Quik JT, Mankiewicz-Boczek J, De Schamphelaere KA Elsaesser A, et al. (2009) Fate and effects of $\mathrm{CeO} 2$ nanoparticles in aquatic ecotoxicity tests. Environ Sci Technol 43: 4537-4546.

25. Garaud M, Trapp J, Devin S, Cossu-Leguille C, Pain-Devin S, et al. (2015) Multibiomarker assessment of cerium dioxide nanoparticle $(\mathrm{nCeO} 2)$ sublethal effects on two freshwater invertebrates, Dreissena polymorpha and Gammarus roeseli. Aquatic Toxicol 158: 63-74

26. Brousseau P, Pillet S, Froin H, Auffret $M$, Gagné $F$, et al. (2012) Linking immunotoxicity and ecotoxicological effects at higher biological levels. In Ecological biomarkers: Indicators of ecotoxicological effects. Taylor and Francis, France.

27. Gagné F, Auclair J, Turcotte P, Fournier M, Gagnon C, et al. (2008) Ecotoxicity of CdTe quantum dots to freshwater mussels: Impacts on immune system oxidative stress and genotoxicity. Aquat Toxicol 86: 333-340.

28. Bruneau A, Turcotte P, Pilote M, Auclair J, Gagné F, Gagnon C (2016) Fate of silver nanoparticles in wastewaters and immunotoxic effects on rainbow trout. Aquat Toxicol 174: 70-81

29. Sager TM, Porter DW, Robinson VA, Lindsley WG, Schwegler-Berry DE, et al. (2007) Improved method to disperse nanoparticles for in vitro and in vivo investigation of toxicity. Nanotoxicity 1: 118-129.

30. Zhu X, Zhu I, Duan Z, Qi R, Li Y, Lang Y (2008) Comparative toxicity of several metal oxide nanoparticle aqueous suspensions to zebrafish (Dania rerio) early development stage. J Environ Sci Health 43: 278-284.

31. O'Brien N, Cummins E (2010) Ranking initial environmental and human health risk resulting from environmentally relevant nanomaterials. J Environ Sci Health Part A 45: 992-1007.

32. Gaiser BK, Fernandes TF, Jepson M, Lead JR, Tyler CR, et al. (2011) Interspecies comparisons on the uptake and toxicity of silver and cerium dioxide nanoparticles. Environ Toxicol Chem 31: 144-154.

33. Bruneau A, Fortier M, Gagne F, Gagnon C, Turcotte P, et al. (2013) Size distribution effects of cadmium tellurium quantum dots (CdS/CdTe) immunotoxicity on aquatic organisms. Env Sci Process Impact 15: 596-607.

34. Rousseau TCC, Sonke JE, Chmeleff J, Candaudap F, Lacan F, et al. (2013) Rare earth element analysis in natural waters by multiple isotope dilution-sector field ICP-MS. J Anal At Spectrum.

35. Bruneau A, Turcotte P, Pilote M, Gagné F, Gagnon C (2015) Fate and immunotoxic effects of silver nanoparticles on rainbow trout in natural waters. $J$ Nanomed Nanotechnol 6: 3 .

36. Gagné F, Fortier M, Fournier M, Gagnon C (2016) Immunotoxicity of zinc oxide nanoparticles and municipal effluents to fathead minnows. Toxicol Open Access 2: 2.

37. Brousseau $P$, Payette $P$, Tryphonas H, Blakley B, Boermans $H$, et al. (1998) Manual of Immunological Methods. Boca Raton FL: CRC Press, Taylor and Francis Group.

38. Gaiser BK, Fernandes TF, Jepson M, Lead JR, Tyler CR, et al. (2009) Assessing exposure, uptake and toxicity of silver and cerium dioxide nanoparticles from contaminated environments. Environmental Health 8: S2.

39. Hussain S, Al-Nsour F, Rice AB, Marshburn J, Yingling B, et al. (2012) Cerium dioxide nanoparticles induce apoptosis and autophagy in human periphera blood monocytes. ACS Nano 6: 5820-5829.

40. Van Hoecke K, De Schamphelaere KAC, Van der Meeren P, Smagghe G 
Citation: Gagnon C, Bruneau A, Turcotte P, Pilote M, Gagné F (2018) Fate of Cerium Oxide Nanoparticles in Natural Waters and Immunotoxicity in Exposed Rainbow Trout. J Nanomed Nanotechnol 9: 489. doi: 10.4172/2157-7439.1000489

Page 8 of 8

Janssen CR (2011) Aggregation and ecotoxicity of $\mathrm{CeO} 2$ nanoparticles in synthetic and natural waters with variable $\mathrm{pH}$, organic matter concentration and ionic strength. Environ Pollut 159: 970-976.

41. Arnold MC, Badireddy AR, Wiesner MR, Di Giulio RT, Myer JN (2013) Cerium oxide nanoparticles are more toxic than equimolar bulk cerium oxide in Caenorhabditis elegans. Arch Environ Contam Toxicol 65: 224-233.

42. Roh JY, Park YK, Park K, Choi J (2010) Ecotoxicological investigation of CeO2 and $\mathrm{TiO} 2$ nanoparticles on the soil nematode Caenorhabditis elegans using gene expression, growth, fertility, and survival as endpoints. Environ Toxicol Pharmacol 29: 167-172.

43. Ciacci C, Canonico B, Bilaniĉovă D, Fabbri R, Cortese K, et al. (2012) Immunomodulation by different types of $\mathrm{N}$-oxides in the hemocytes of the marine bivalve Mytilus galloprovincialis. PLoS One 7: e36937.
44. Zeyons O, Thill A, Chauvat F, Menguy N, Cassier-Cahauvat C, et al. (2009) Direct and indirect $\mathrm{CeO} 2$ nanoparticles toxicity for Escherichia coli and Synechocystis. Nanotoxicology 3: 284-295.

45. Skorodumova N, Simak S, Lundqvist BI, Abrikosov I, Johansson B (2002) Quantum origin of the oxygen storage capability of ceria. Phys Rev Lett 89 : 166601.

46. Pirmohamed T, Dowding JM, Singh S, Wasserman B, Heckert E, et al. (2010) Nanoceria exhibit redox state-dependent catalase mimetic activity. Chem Commun 46: 2736-2738.

47. Heckert EG, Karakoti AS, Seal S, Self WT (2008) The role of cerium redox state in the SOD mimetic activity of nanoceria. Biomaterials 29: 2705-2709. 